\title{
The composition of mineral waters sourced from Europe and North America in respect to bone health: composition of mineral water optimal for bone
}

\author{
Emma Wynn ${ }^{1}$, Eric Raetz ${ }^{2}$ and Peter Burckhardt ${ }^{3}$ \\ ${ }^{1}$ Centre of Bone Diseases, University Hospital, Lausanne, Switzerland \\ ${ }^{2}$ Service de la Consommation et des Affaires Vétérinaires, Epalinges, Switzerland \\ ${ }^{3}$ Clinic Bois-Cerf, Osteoporosis Consultation, Lausanne, Switzerland \\ (Received 28 March 2008 - Revised 29 July 2008 - Accepted 30 July 2008 - First published online 8 September 2008)
}

The consumption of mineral waters is increasing in industrialised countries. High intakes of Ca and other alkalising cations as well as a low acid intake are beneficial to bone. We examined which components of mineral waters are conditioning their Ca content and their alkalinising power, in order to define the optimal profile. European mineral waters were randomly selected on the Internet: 100 waters with less than $200 \mathrm{mg} \mathrm{Ca} / \mathrm{l}$ $(9.98 \mathrm{mEq} / \mathrm{l})$ and fifty with more than $200 \mathrm{mg} / \mathrm{l}$, all with complete data for $\mathrm{SO}_{4}, \mathrm{P}, \mathrm{Cl}, \mathrm{Na}, \mathrm{K}, \mathrm{Mg}$ and $\mathrm{Ca}$, and most also for $\mathrm{HCO}_{3}$. For comparison, forty North American mineral waters were randomly chosen. The potential renal acid load (PRAL) was calculated for each mineral water. North American waters did not reveal significant results because of their low mineralisation. We performed correlations between all eight components in order to explore the properties of the mineral waters. In the European waters, twenty-six out of twenty-eight correlations showed a $P$ value of $\leq 0.01$. In waters with PRAL $>0$ (acidifying waters), PRAL was positively correlated with $\mathrm{SO}_{4}, \mathrm{Ca}, \mathrm{K}$ and $\mathrm{Mg}(P<0 \cdot 001)$. In those with PRAL $<0$ (alkalinising waters), PRAL was negatively correlated with $\mathrm{HCO}_{3}, \mathrm{Na}, \mathrm{Mg}, \mathrm{Ca}, \mathrm{K}, \mathrm{Cl}$ and $\mathrm{SO}_{4}(P<0 \cdot 001) . \mathrm{SO}_{4}$ and $\mathrm{HCO}_{3}$ were not found together in high quantities in the same water for geochemical reasons. A high Ca content is associated with either a high $\mathrm{SO}_{4}$ or a high $\mathrm{HCO}_{3}$ content. $\mathrm{SO}_{4}$ theoretically increases $\mathrm{Ca}$ excretion, while $\mathrm{HCO}_{3}$ and low PRAL values are associated with positive effects on bone. Therefore, the best waters for bone health are rich in both $\mathrm{HCO}_{3}$ and $\mathrm{Ca}$, and by consequence low in $\mathrm{SO}_{4}$.

Acid-base balance: Potential renal acid load: Mineral water: Calcium metabolism: Bone health

The origins of mineral water can be traced back to early civilisation. The Romans searched for drinking water sources and developed them while establishing their empire ${ }^{(1)}$. In the last few years, the consumption of mineral waters and bottled waters has increased ${ }^{(2)}$. Over the last decade, for example, the consumption of mineral water has more than doubled in the USA and Switzerland. Mineral waters now have a prominent place in the industrialised countries' $\operatorname{diet}^{(3)}$. For this reason, their impact on health needs to be assessed ${ }^{(2)}$. Several studies have already focused on the effect on bone ${ }^{(4,5)}$. In this context, high $\mathrm{Ca}$ and bicarbonate content has been revealed to be beneficial ${ }^{(6-8)}$. We therefore analysed the conditions that favour these two components.

The present study focuses on mineral waters only. Indeed, there are different types of bottled water: spring or artesian water, well water, purified water and sparkling bottled water $^{(9)}$.

Natural mineral water distinguishes itself from other bottled waters by its specific underground geological origin, its stable composition of minerals and its original purity ${ }^{(1)}$. To avoid any alteration, natural mineral water must be bottled at the source and can only undergo a strictly limited number of expressly authorised treatments.
According to the geological patterns of the catchment areas, very large variations exist in the composition of different mineral waters ${ }^{(9)}$. Therefore, mineral waters can have potential beneficial or harmful effects on health, including bone health. Several mineral waters have a beneficial effect on bone metabolism which so far has mainly been attributed to their $\mathrm{Ca}$ content ${ }^{(4,5,7,10-12)}$. Ca-rich mineral waters have been shown to be an alternative to dairy products as the $\mathrm{Ca}$ bioavailability is similar or even possibly better ${ }^{(13)}$. They have also been shown to decrease bone resorption ${ }^{(7)}$. The mineral cations together with the bicarbonate also seem to play an important role ${ }^{(8,14)}$. They may decrease bone resorption and increase bone mineral density due to these waters' alkalinity.

Alkalinising mineral waters can influence the acid-base equilibrium of the body ${ }^{(15)}$. Even small changes in $\mathrm{pH}$ have crucial effects on cellular function.

In vitro studies have shown that metabolic acidosis induces $\mathrm{Ca}$ efflux from bone due to increased bone resorption ${ }^{(16)}$. A moderate increase in the intake of alkaline equivalents reduced bone resorption, increased bone formation and improved $\mathrm{Ca}$ balance in postmenopausal women ${ }^{(17)}$. The acidification of bone not only enhances osteoclastic activity but also inhibits osteoblasts by reducing collagen synthesis and

Abbreviation: PRAL, potential renal acid load.

* Corresponding author: Emma Wynn, fax +41 2131443 10, email emma.wynn@chuv.ch 
mineralisation $^{(18,19)}$. Furthermore, studies conducted in animals and human subjects have demonstrated that an acid environment is associated with a negative $\mathrm{Ca}$ balance and increased bone loss ${ }^{(20-22)}$.

Nutrition has long been known to strongly influence the acid-base balance in humans ${ }^{(23)}$, with a positive association between the consumption of alkali-forming foods such as fruit and vegetables and bone health ${ }^{(24)}$. In healthy subjects, the administration of potassium bicarbonates, potassium citrate and even mineral water rich in bicarbonates allowed a decrease in calciuria and of bone resorption markers ${ }^{(6,17,25,26)}$.

The in vitro measurement of the acid-base ratio of diets is the calculation model developed by Remer \& Manz ${ }^{(27)}$. It can also be applied to mineral waters. We therefore determined the potential renal acid load (PRAL) values of 150 European mineral waters and examined the question of which nutritional components are conditioning the acidity or alkalinity of mineral waters and their $\mathrm{Ca}$ content, in order to define the optimal profile for a positive effect on bone.

\section{Methods}

A total of 150 European mineral waters were randomly selected on the Internet ${ }^{(28)}$. We included 100 waters with a $\mathrm{Ca}$ content of $<200 \mathrm{mg} / \mathrm{l}(<9.98 \mathrm{mEq} / \mathrm{l})$ and fifty waters with a Ca content $>200 \mathrm{mg} / \mathrm{l}(>9.98 \mathrm{mEq} / \mathrm{l})$. The Internet site describes the mineral content of commercially available mineral waters, most of which we verified via their home Internet sites when available. Their complete nutritional composition was collected. Only waters with complete nutritional data for $\mathrm{SO}_{4}, \mathrm{Cl}, \mathrm{Na}, \mathrm{K}, \mathrm{Mg}$ and $\mathrm{Ca}$ were selected. The bicarbonate content of water was collected when available. $\mathrm{pH}$ values could not be included in this analysis because they were very rarely indicated. Anyway, the $\mathrm{pH}$ of mineral water is not necessarily related to its acidifying or alkalinising effect on the body.

For comparison, forty North American mineral waters were randomly chosen (twenty Canadian waters and twenty American waters).

The PRAL index was calculated for each individual water with the following nutrients using the formula ${ }^{(27)}$ :

$$
\begin{aligned}
\operatorname{PRAL}(\mathrm{mEq} / \mathrm{d})= & (\text { chloride }(\mathrm{mg} / \mathrm{d}) \times 0.03+\operatorname{protein}(\mathrm{g} / \mathrm{d}) \\
& \times 0.49)-(\mathrm{K}(\mathrm{mg} / \mathrm{d}) \times 0.021+\mathrm{Mg}(\mathrm{mg} / \mathrm{d}) \\
& \times 0.0263+\mathrm{Ca}(\mathrm{mg} / \mathrm{d}) \times 0.013 \\
& +\mathrm{Na}(\mathrm{mg} / \mathrm{d}) \times 0.04) .
\end{aligned}
$$

The index takes into account the average intestinal absorption rate of the respective components. The Consensus paper published following the 2nd International Symposium on Acid Base Balance (Munich, 2006) suggests using the term net endogenous acid production, which includes a factor for organic acids ${ }^{(29)}$. Since we did not relate the calculations of Remer's formula to body surface area for calculating the organic acids, we just used the dietary value estimates. Therefore we used PRAL in the present paper. The phosphate content of mineral water is negligible and for this reason not indicated by the manufacturers. Therefore, we did not include it.
The conversion factor concerning protein is explained by the intake of methionine and cysteine which are the natural sources of $\mathrm{SO}_{4}$. This cannot be applied to mineral waters. In mineral waters, $\mathrm{SO}_{4}$ is in solution. This justifies a correction of the formula by using the molecular weight of $\mathrm{SO}_{4}$ (instead of the two amino acids), which is 96 , and an absorption rate of $70 \%$, resulting in a conversion factor of 0.0146 instead of 0.00049 (T Remer, personal communication, 2007).

Knowing the composition of the mineral waters and their PRAL values it was possible to examine the question of which constituents favour high $\mathrm{Ca}$ content and alkalinity.

\section{Statistical analysis}

All analyses were performed by using the SPSS statistical software package (version 15.0; SPSS Inc., Chicago, IL, USA). Descriptive statistics were determined for all variables. Data were checked for normality with the Kolmogorov-Smirnov test. Since all variables were not normally distributed, Spearman correlations and Mann-Whitney $U$ tests were undertaken. Stepwise multiple regression analysis was used to determine which nutrients were the most predictive of the estimate of PRAL and of Ca content.

\section{Results}

\section{All 150 mineral waters}

The characteristics of the 150 European mineral waters are shown in Table 1 . As expected, there is a very great variability in the composition of the different waters. $\mathrm{HCO}_{3}$ is the component found in the largest quantities and $\mathrm{K}$ the one found in the smallest quantities. Out of the twenty-eight correlations between the different components, twenty-six had a $P$ value of $\leq 0.01$, except for PRAL-Mg and PRAL-Cl. Twentyone out of the twenty-eight correlations had a $P$ value of $<0.001$. Among those, the most significant ones $(r>0.700)$ were: $\mathrm{Na}-\mathrm{Cl}(r$ 0.829), $\mathrm{Na}-\mathrm{K}(r$ 0.784) and $\mathrm{Ca}-\mathrm{Mg}$ ( $r$ 0.741). The strong correlations between $\mathrm{Na}$ and $\mathrm{K}$, and between $\mathrm{Mg}$ and $\mathrm{Ca}$, can be explained by the parent chemical features of these elements (alkaline metals and alkaline earth metals, respectively). The strongest (negative) correlation for PRAL is the one with $\mathrm{HCO}_{3}$ (Fig. 1). On the other hand, PRAL- $\mathrm{SO}_{4}$ shows a significant (positive) correlation for mineral waters with PRAL $>0$ (Fig. 2). $\mathrm{SO}_{4}$ and $\mathrm{HCO}_{3}$ are not found together in high quantities in the same water (Fig. 3). The correlation between $\mathrm{Ca}$ and sulfate is only strong for waters with low bicarbonate contents, except in one exceptional mineral water for which both sulfate and bicarbonate are simultaneously high (Fig. 4). The stepwise regression analysis included PRAL and all the minerals. $\mathrm{Na}$ was the principal negative significant predictor and explained $73 \%$ of PRAL $(P<0.001)$. The stepwise regression analysis for $\mathrm{Ca}$ also included all the minerals. $\mathrm{SO}_{4}$ was the principal positive significant predictor and explained $60.3 \%$ of $\mathrm{Ca}$ $(P<0 \cdot 001)$.

Assuming that relationships between the components are fundamentally different between alkalinising and acidifying waters, we divided the data for further analysis into two groups: waters with PRAL $<0(n$ 105) and PRAL $>0(n$ 45). 
Table 1. Composition of the mineral waters

(Mean values)

\begin{tabular}{|c|c|c|c|c|c|c|c|c|}
\hline \multirow[b]{2}{*}{ Mean‡ } & \multicolumn{2}{|c|}{$\begin{array}{l}\text { European mineral } \\
\text { waters }(n 150)\end{array}$} & \multicolumn{2}{|c|}{$\begin{array}{l}\text { European mineral waters } \\
\text { with PRAL }<0(n 105)\end{array}$} & \multicolumn{2}{|c|}{$\begin{array}{l}\text { European mineral waters } \\
\text { with PRAL }>0(n 45)\end{array}$} & \multicolumn{2}{|c|}{$\begin{array}{c}\text { North American mineral } \\
\text { waters }(n 40)\end{array}$} \\
\hline & $\mathrm{mEq} / \mathrm{l}$ & $\mathrm{Mg} / \mathrm{l}$ & $\mathrm{mEq} / \mathrm{l}$ & $\mathrm{mg} / \mathrm{l}$ & $\mathrm{mEq} / \mathrm{l}$ & $\mathrm{mg} / \mathrm{l}$ & $\mathrm{mEq} / \mathrm{l}$ & $\mathrm{mg} / \mathrm{l}$ \\
\hline $\mathrm{HCO}_{3} \S$ & $10 \cdot 01$ & 611 & 11.68 & 713 & 5.62 & 343 & $3.29 \dagger$ & 201 \\
\hline $\mathrm{SO}_{4}$ & 5.41 & 260 & $1 \cdot 10$ & 53 & $15 \cdot 47^{\star}$ & 743 & $2 \cdot 73 \dagger$ & 131 \\
\hline $\mathrm{Ca}$ & 8.93 & 179 & 5.74 & 115 & $16 \cdot 02^{*}$ & 328 & $2.94 \dagger$ & 59 \\
\hline $\mathrm{Na}$ & 5.24 & 120 & 5.96 & 137 & 3.55 & 82 & $2.74 \dagger$ & 63 \\
\hline $\mathrm{Cl}$ & 2.06 & 73 & 1.41 & 50 & 3.63 & 129 & $0.93 \dagger$ & 33 \\
\hline $\mathrm{Mg}$ & $3 \cdot 21$ & 39 & 2.71 & 33 & $4.52^{*}$ & 55 & $1.40 \dagger$ & 17 \\
\hline K & 0.26 & 10 & 0.33 & 13 & 0.15 & 6 & 0.09 & 3.5 \\
\hline PRAL & -2.4 & & -5.9 & & $5 \cdot 63^{*}$ & & -0.9 & \\
\hline
\end{tabular}

PRAL, potential renal acid load.

* Mean value was significantly different from that for waters with PRAL $<0(P<0.01$; Mann-Whitney $U$ test $)$.

$\dagger$ Mean value was significantly different from that for European waters $(P<0.01$; Mann-Whitney $U$ test).

¥ Standard deviations are irrelevant because of totally abnormal distribution.

$\S n 142, n 103, n 39$ and $n 34$ for European mineral waters, European mineral waters with PRAL $<0$, European mineral waters with PRAL $>0$ and North American mineral waters, respectively.

The 105 mineral waters with potential renal acid load $<0$

Of the 150 mineral waters, $105(70 \%)$ have a negative PRAL and are therefore alkalinising. $\mathrm{HCO}_{3}$ is the most important component quantitatively. All twenty-eight correlations showed a $P$ value of $\leq 0 \cdot 001$. The most positive significant correlations $(r>0.7)$ were those between $\mathrm{Na}, \mathrm{Cl}, \mathrm{K}$ and $\mathrm{HCO}_{3}$, those between $\mathrm{HCO}_{3}, \mathrm{~K}$ and $\mathrm{Mg}$, and that between $\mathrm{K}$ and $\mathrm{Cl}$. PRAL was negatively correlated with all constituents with a $P$ value of $<0 \cdot 001$. The stepwise regression analysis included PRAL and all the minerals. Na was the principal negative significant predictor and explained $89.3 \%$ of PRAL $(P<0 \cdot 001)$. The stepwise regression analysis for $\mathrm{Ca}$ also included all the minerals. $\mathrm{HCO}_{3}$ was the principal positive significant predictor and explained $26.5 \%$ of $\mathrm{Ca}(P<0.001)$.

\section{The forty-five mineral waters with potential renal}

acid load $>0$

Of the 150 mineral waters, forty-five $(30 \%)$ have a positive PRAL and are therefore acidifying. $\mathrm{SO}_{4}$ is the most important component quantitatively, revealing waters originating from gypsous origins (hydrated calcium sulfate; $\mathrm{CaSO}_{4} \cdot 2 \mathrm{H}_{2} \mathrm{O}$ ). Correlations with $P$ values of $<0.001$ were only found in: $\mathrm{Ca}-\mathrm{SO}_{4}, \mathrm{Ca}-\mathrm{Mg}, \mathrm{Mg}-\mathrm{SO}_{4}, \mathrm{Na}-\mathrm{Cl}$ and $\mathrm{Na}-\mathrm{K}$. In addition, PRAL was positively correlated $(P<0.001)$ with $\mathrm{SO}_{4}, \mathrm{Ca}$

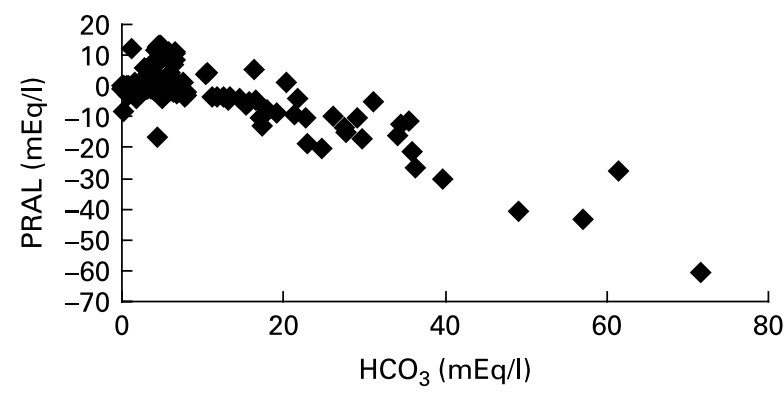

Fig. 1. Correlation between potential renal acid load (PRAL) in $\mathrm{mEq} / \mathrm{l}$ and bicarbonate $\left(\mathrm{HCO}_{3}\right)$ in $\mathrm{mEq} / \mathrm{l}$ in 142 European mineral waters $\left(y=-0.6822 x+3.9505 ; R^{2} 0.7187\right)$. and $\mathrm{Mg}$. The stepwise regression analysis included PRAL and all the minerals. $\mathrm{SO}_{4}$ was the principal positive significant predictor and explained $95 \%$ of PRAL $(P<0 \cdot 001)$. The stepwise regression analysis for $\mathrm{Ca}$ also included all the minerals. $\mathrm{SO}_{4}$ was the principal positive significant predictor and explained $83.8 \%$ of $\mathrm{Ca}(P<0.001)$.

\section{The forty mineral waters from North America}

The forty North American mineral waters were significantly different from the 150 European mineral waters for all nutrients except for $\mathrm{K}$ and PRAL. The mean values for the different nutrients were much lower than the European mineral waters. The randomly chosen North American mineral waters were weakly mineralised.

\section{Discussion}

In these 150 European mineral waters, the degree of mineralisation varies tremendously. Of the 150 mineral waters, $70 \%$ have a negative PRAL and are therefore alkalinising and $30 \%$ have a positive PRAL and are therefore acidifying. Several components condition these characteristics of water. $\mathrm{SO}_{4}$ and $\mathrm{Cl}$ are acidifying components and $\mathrm{Na}, \mathrm{K}, \mathrm{Mg}$ and $\mathrm{Ca}$

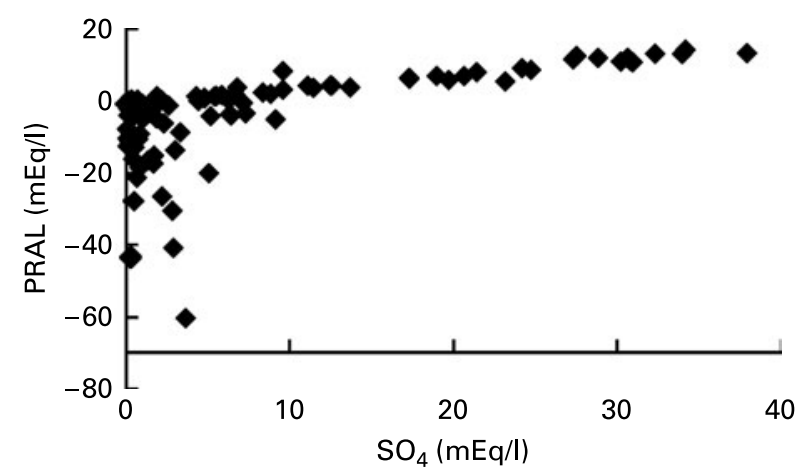

Fig. 2. Correlation between potential renal acid load (PRAL) in mEq/l and sulfate $\left(\mathrm{SO}_{4}\right)$ in $\mathrm{mEq} / \mathrm{l}$ in 150 European mineral waters $\left(y=2.2762 x-5.4855 ; R^{2} 0.2635\right)$. 


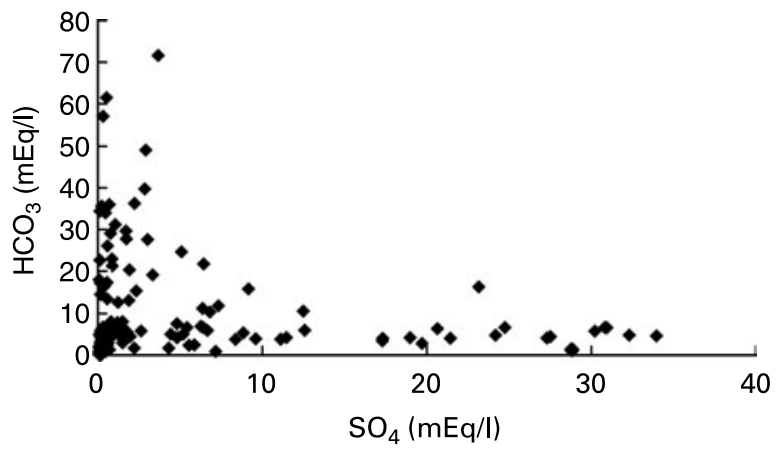

Fig. 3. Correlation between bicarbonate $\left(\mathrm{HCO}_{3}\right)$ in $\mathrm{mEq} / \mathrm{l}$ and sulfate $\left(\mathrm{SO}_{4}\right)$ in $\mathrm{mEq} / \mathrm{l}$ in 150 European mineral waters $(y=-0.1953 x+10.973$ $R^{2}$ 0.0167).

are alkalinising components as seen in the PRAL algorithm. Waters originating from gypsous aquifers will show high contents in $\mathrm{Ca}$ and sulfate and for this reason have an acidifying PRAL. The beneficial effect of such waters on bone can be questioned. $\mathrm{SO}_{4}$ could increase $\mathrm{Ca}$ excretion. According to animal data, sulfate supplementation leads to increased $\mathrm{Ca}$ excretion $^{(30-32)}$. In human subjects, however, the results are contradictory: sulfates either have no effect ${ }^{(33)}$ or increase calciuria due to their acidogenic action ${ }^{(34)}$. Indeed, acid load increases urine $\mathrm{Ca}$ excretion ${ }^{(34)}$. On the other hand, several studies have shown that alkalinising mineral waters low in $\mathrm{SO}_{4}$ and rich in $\mathrm{HCO}_{3}$ had better effects on $\mathrm{Ca}$ metabolism and bone resorption markers than waters rich in $\mathrm{SO}_{4}$ and $\mathrm{Ca}^{(8,35)}$. The inhibition of bone resorption by Ca-rich mineral water has already been shown, but in Ca-deficient, postmenopausal women ${ }^{(7,36)}$. In $\mathrm{Ca}$ - and oestrogen-sufficient women, an acid Ca-rich water had no effect on bone resorption, while an alkaline water rich in bicarbonate led to a significant decrease of parathyroid hormone and of bone resorption markers $^{(35)}$. To obtain a positive effect on bone metabolism it would be advisable to use waters rich in $\mathrm{Ca}$, high in bicarbonate and low in $\mathrm{SO}_{4}$.

The statistical analysis examines which mineral water composition favours high $\mathrm{Ca}$ content. Significant correlations between the components are found independently from the degree of mineralisation. Cations and anions must be in equal quantities to ensure electrical balance. In Ca-rich water, the presence of a bivalent anion or, alternatively, of

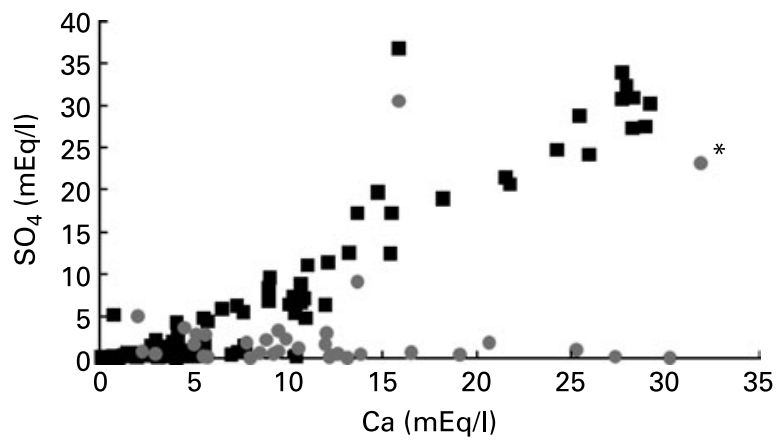

Fig. 4. Correlation between sulfate $\left(\mathrm{SO}_{4}\right)$ in $\mathrm{mEq} / \mathrm{l}$ and $\mathrm{Ca}$ in $\mathrm{mEq} / \mathrm{l}$ in 150 European mineral waters, separated by bicarbonate values $>11.8 \mathrm{mEq} / \mathrm{l}(\bullet)$ or $<11.8 \mathrm{mEq} / \mathrm{l}(\mathbf{\square})\left(y=1.1069 x-2.5277 ; R^{2} 0.9284\right) .{ }^{*}$ This unique outlier has an unusual geological origin (meteoritic rocks; see Discussion). two monovalent anions, is required to balance the bivalent $\mathrm{Ca}$, such as $\mathrm{SO}_{4}$ or $\mathrm{HCO}_{3}$. High-Ca waters have therefore also high contents of either sulfate or bicarbonate but not of both (Fig. 3). This feature can be explained by the geological conditions and particularly the geochemistry prevailing at the time period the aquifer was being formed. In the case of rocks originating from sea sediments, layers are of different composition according to the solubility of the available salts. Owing to their lower solubility, carbonates precipitated and were deposited first, followed later by sulfates (forming gypsum if associated with $\mathrm{Ca}$ ), and eventually, in less frequent cases, by halides (such as sodium chloride). Bicarbonate and sulfate are not present in the same layers and therefore not commonly found together in high amounts in mineral waters. Exceptions seem to be rare since we only found one (see the outlier in Fig. 4). The particularity of this outlier is its very high contents of $\mathrm{Ca}$ and the presence of both $\mathrm{SO}_{4}$ and $\mathrm{HCO}_{3}$ in high quantities. This case can possibly be explained by its unusual geological origin (meteoritic rocks).

In Fig. 2, increasing $\mathrm{SO}_{4}$ from 5 to $40 \mathrm{mEq}$ increases PRAL by approximately only $10 \mathrm{mEq}$. Something must be neutralising the presumed acid load for PRAL not to increase more. This could be the increasing $\mathrm{Ca}$ content in those waters which have a $\mathrm{HCO}_{3}$ content $<11.8 \mathrm{mEq}$ as shown in Fig. 4 .

Although $\mathrm{Na}$ is not a main predictor of $\mathrm{Ca}$, it is, however, one of the nutrients used to calculate PRAL and, because of that, potentially favourable for effects on bone. But $\mathrm{Na}$ increases urinary $\mathrm{Ca}$ excretion and is not advisable in cardiac and renal patients. Therefore, the $\mathrm{Na}$ content should not be high. This is not a problem because mineral waters rich in $\mathrm{Ca}$ and bicarbonate are relatively low in $\mathrm{Na}$, i.e. below $500 \mathrm{mg} \mathrm{Na} / \mathrm{l}$.

We had planned to compare the European waters with a group of forty North American waters. There are important differences between the regulations for mineral water in Europe and North America ${ }^{(37)}$. In the USA, the Food and Drug Administration requires that mineral waters contain between 500 and $1500 \mathrm{mg}$ of total dissolved minerals per litre, whereas Europe considers water as mineral water whatever the level of mineralisation ${ }^{(37)}$. This leads to a selection bias and prevents any comparison. Moreover, the North American mineral waters are very poorly mineralised compared with European ones.

In conclusion, we found that a high $\mathrm{Ca}$ content in mineral water is associated with either high sulfate contents or high bicarbonate contents. A high $\mathrm{SO}_{4}$ content and therefore a more acidifying water could increase $\mathrm{Ca}$ excretion. Since high bicarbonate together with mineral cations provide positive effects on $\mathrm{Ca}$ metabolism, it can be concluded that the best waters would be rich in both bicarbonate and mineral cations including $\mathrm{Ca}$. This also corresponds to waters low in sulfate.

This combination is found in $12 \%$ of the 150 studied European waters with $\mathrm{Ca}>200 \mathrm{mg} / \mathrm{l}(>9.98 \mathrm{mEq} / \mathrm{l})$ and bicarbonate $>700 \mathrm{mg} / \mathrm{l}(>11.8 \mathrm{mEq} / \mathrm{l})$.

\section{Acknowledgements}

The present study was supported by the Foundation for Research on Osteoporosis and Bone Diseases (Lausanne, Switzerland). 
None of the authors has any conflict of interest.

E. W. performed the study and wrote the manuscript. E. R. provided scientific supervision. $\mathrm{P}$. B. wrote the research protocol, directed and coordinated the study and supervised the manuscript.

\section{References}

1. Petraccia L, Liberati G, Masciullo S, Grassi M \& Fraioli A (2006) Water, mineral waters and health. Clin Nutr 25, $377-385$.

2. Garzon P \& Eisenberg M (1998) Variation in the mineral content of commercially available bottled waters: implications for health and disease. Am J Med 105, 125-130.

3. Doria M (2006) Bottled water versus tap water: understanding consumer's preference. J Water Health 4, 271-276.

4. Burckhardt P (2004) Mineral waters: effects on bone and bone metabolism. In Nutritional Aspects of Osteoporosis, pp. 439-447 [P Burckhardt, B Dawson-Hughes and RP Heaney, editors]. San Diego, CA: Elsevier Science.

5. Burckhardt $P$ (2003) The effect of mineral waters on bone metabolism and bone health. In Nutritional Aspects of Bone Health, pp. 313-321 [S New and J Bonjour, editors]. Cambridge, UK: The Royal Society of Chemistry.

6. Burckhardt P, Waldvogel S, Aeschlimann J \& Arnaud M (2002) Bicarbonate in mineral water inhibits bone resorption. Abstract M360. J Bone Miner Res 17, Suppl. 1, S476.

7. Meunier $\mathrm{P}$, Jenvrin $\mathrm{C}$, Munoz $\mathrm{F}$, de la Gueronnière $\mathrm{V}$, Garnero $\mathrm{P}$ \& Menz M (2005) Consumption of a high calcium mineral water lowers biochemical indices of bone remodelling in postmenopausal women with low calcium intake. Osteoporos Int 16, 1203-1209.

8. Roux S, Baudoin C, Boute $\mathrm{D}$, Brazier $\mathrm{M}$, De la Gueronnière V \& De Vernejoul M (2004) Biological effects of drinking-water mineral composition on calcium balance and bone remodeling markers. J Nutr Health Aging 8, 380-384.

9. Kerstetter J \& Allen L (1989) Dietary protein increases urinary calcium. $J$ Nutr 120, 134-136.

10. Heaney RP (2006) Absorbability and utility of calcium in mineral waters. Am J Clin Nutr 84, 371-374.

11. Cepollaro C, Orlandi G, Gonnelli S, Ferrucci G, Arditti J, Borracelli D, Toti E \& Gennari C (1996) Effect of calcium supplementation as a high-calcium mineral water on bone loss in early postmenopausal women. Calcif Tissue Int 59, 238-239.

12. Costi D, Calcaterra P, Iori N, Vourna S, Nappi G \& Passeri M (1999) Importance of bioavailable calcium drinking water for the maintenance of bone mass in post-menopausal women. $J$ Endocrinol Invest 22, 852-856.

13. Böhmer H, Müller H \& Resch K (2000) Calcium supplementation with calcium-rich mineral waters: a systemic review and metaanalysis of its bioavailability. Osteoporos Int 11, 938-943.

14. Buclin T, Cosma M, Appenzeller M, Jacquet A, Décosterd L, Boillaz J \& Burckhardt P (2001) Diet acids and alkalis influence calcium retention in bone. Osteoporos Int 12, 493-499.

15. Burckhardt $\mathrm{P}$ (2008) The effect of the alkali load of mineral water on bone metabolism: interventional studies. J Nutr 138, 435S-437S.

16. Buchinsky D \& Frick K (2000) The effects of acid on bone. Curr Opin Nephrol Hypertens 9, 369-379.

17. Sellmeyer D, Schloetter M \& Sebastian A (2002) Potassium citrate prevents increased urine calcium excretion and bone resorption induced by a high sodium chloride diet. $J$ Clin Endocrinol Metab 87, 2008-2012.

18. Bushinsky D (1995) Stimulated osteoclastic and suppressed osteoblastic activity in metabolic but not respiratory acidosis. Am J Physiol 268, C80-C88.
19. Frick K \& Bushinsky D (1998) Chronic metabolic acidosis reversibly inhibits extracellular matrix gene bin mouse osteoblasts. Am J Physiol 275, F840-F847.

20. Lemann J, Litzow J \& Lennon E (1966) The effects of chronic acid loads in normal man: further evidence for the participation of bone mineral in defense against chronic metabolic acidosis. $J$ Clin Invest 45, 1608-1614.

21. Barzel U \& Jowsey J (1969) The effects of chronic acid and alkali administration on bone turnover in adult rats. Clin Sci 36, 517-524.

22. Tucker K, Hannan M \& Kiel D (2001) The acid-base hypothesis: diet and bone in the Framingham Osteoporosis Study. Eur $J$ Nutr 40, 231-237.

23. Remer T (2000) Influence of diet on acid-base balance. Semin Dial 13, 221-226.

24. New S, Robins S, Campbell M, Martin J, Garton M, BoltonSmith C, Grubb DA, Lee SJ \& Reid DM (2000) Dietary influences on bone mass and bone metabolism: further evidence of a positive link between fruit and vegetable consumption and bone health? Am J Clin Nutr 71, 142-151.

25. Jehle S, Zanetti A, Muser J, Hulter H \& Krapf R (2006) Partial neutralization of the acidogenic Western diet with potassium citrate increases bone mass in postmenopausal women with osteopenia. J Am Soc Nephrol 17, 3213-3222.

26. Sebastian A, Harris S, Ottaway J, Todd K \& Morris C (1994) Improved mineral balance and skeletal metabolism in postmenopausal women treated with potassium bicarbonate. $N$ Engl $J$ Med 330, 1776-1781.

27. Remer T \& Manz F (1995) Potential renal acid load of foods and its influence on urine pH. J Am Diet Assoc 95, 791-797.

28. Anonymous (2007) Water from all over the World. www.mineral waters.org (accessed December 2007).

29. Frassetto L, Lanham-New S, Macdonald H, Remer T, Sebastian A, Tucker K \& Tylavski FA (2007) Standardizing terminology for estimating the diet-dependent net acid load to the metabolic system. J Nutr 137, 1491-1492.

30. Green T \& Whiting S (1994) Potassium bicarbonate reduces high protein-induced hypercalciuria in adult men. Nutr Res 14, 991-1002.

31. Walser M \& Browder A (1959) The effect of sulfate infusion on calcium excretion. J Clin Invest 38, 1404-1411.

32. Guéguen L \& Besançon P (1972) Effect of sulfates on phosphorus and calcium metabolism. Utilization of calcium sulfate by sheep. Ann Biol Anim Biochim Biophys 12, 589-598.

33. Fardellone P, Bellony R, Texier C, Brazier M, Delabroise AM, Arnaud MJ \& Sebert JL (1996) Comparative study of calcium bioavailability of a high-calcium mineralized water. Osteoporos Int 6, Suppl. 1, 269, abstract PTU 747.

34. Brandolini $\mathrm{M}$, Guéguen L, Boirie $\mathrm{Y}$, Rousset $\mathrm{P}$, Bertière $\mathrm{M} \&$ Beaufrère B (2005) Higher calcium urinary loss induced by a calcium sulphate-rich mineral water intake than by milk in young women. Br J Nutr 93, 225-231.

35. Wynn Dumartheray E, Krieg M \& Burckhardt P (2006) Bicarbonate from mineral water lowers bone resorption even in calcium sufficiency. In Nutritional Aspects of Osteoporosis, pp. 303-309 [P Burckhardt, RP Heaney and B DawsonHughes, editors]. Amsterdam: Elsevier.

36. Guillemant J, Huyen-Tran L, Accarie C, Tézenas du Montcel S, Delabroise A-M, Arnaud M \& Guillemant S (2000) Mineral water as a source of dietary calcium: acute effects on parathyroid function and bone resorption in young men. Am J Clin Nutr 71, 999-1002.

37. Azoulay A, Garzon P \& Eisenberg M (2001) Comparison of mineral content of tap water and bottled waters. J Gen Intern Med 16, 168-175. 